\title{
PERANG DAN JIHAD DALAM PERSPEKTIF FIQH SIYASAH DAULIYAH (TELAAH HISTORIS BERBASIS TEKS SUCI)
}

\author{
M.Junaidi \\ mj122@ums.ac.id
}

\begin{abstract}
Abstraksi
7 ulisan ini bertujuan untuk menjelaskan makna jihad dalam Fiqh siyasah dauliyah, yang selama ini banyak menghubungkan jihad dengan kegiatan destruktif yang menebar teror. Untuk itulah penulis terpanggil untuk menggali implementasi jihad dalam ketatanegaraan islam melalui penyelusuran sejarah peperangan yang pernah dilakukan rasulullah bersama para sahabat. Penulis menggunakan Metode deskripsi dengan pendekatan normatif historis. Penulis mengidentifiksi ayat ayat al qur'an dan hadist rasulullah yang berkenaan dengan peperangan. Kemudian penulis menggambarkan realitas sejarah peperangan yang pernah terjadi pada masa rasulullah dan sahabat. Hal ini dilakukan untuk membuktikan bahwa perang dalam islam tidak sekedar penaklukan kota, merampas harta benda dan mengislamkan penduduk kota yang dilandasi hawa nafsu. Namun perang dalam tata negara islam lebih untuk berdakwah untuk meninggikan kalimat Allah dan pembebasan manusia dari kehidupan "jahiliyah". Sehingga pada Akhirnya penulis berkesimpulan bahwa bahwa perang atau jihad dalam ketatanegaraan islam tidak hanya perang an sich. Namun perang dalam islam merupakan Ibadah sama halnya dengan ibadah sholat, puasa dan lain lain yang memiliki aturan dan tata cara yang bersumber dari alqur'an dan hadist rasulullah.
\end{abstract}

\section{PENDAHULUAN}

Fiqh siyasah dauliyah merupakan dalam lingkup kajian Ketatanegaraan islam, yang mana merupakan kajian akademik mengenai kekuasaan dan keteraturan masyarakat dalam perspektif agama islam yang mencakup hukum, dogma, tradisi, sejarah dan pemikiran tokoh. Termasuk juga di dalam ketatanegaraan islam mengenai perang untuk menjaga kedaulatan wilayah. Istilah perang banyak yang menyamakannya dengan seruan jihad. ${ }^{1}$

Membicarakan jihad saat sekarang ini tidak mudah, dikarenakan ada unsur politis yang sangat subyektif. Untuk sebagian pihak, jihad adalah esensi dari ideologi kelompok Islam radikal bahkan disamakan dengan terorisme. Namun bagi sebagian yang lain, jihad adalah suatu kerja keras spritual yang bersifat damai, individual dan internal. Jihad merupakan amal kebaikan yang disyariatkan Allah. Jihad menjadi sebab kokoh dan mulianya umat Islam. Sebaliknya, jika kaum Muslimin meninggalkan jihad di jalan Allah, maka mereka akan mendapatkan kehinaan. Akan tetapi, amal kebaikan ini harus memenuhi syarat ikhlas dan sesuai dengan syari'at Islam. Pentingnya ajaran jihad dalam Islam antara lain tercermin dalam ayat al-Qur'an dan Hadis Nabi SAW, yang artinya sebagai berikut :
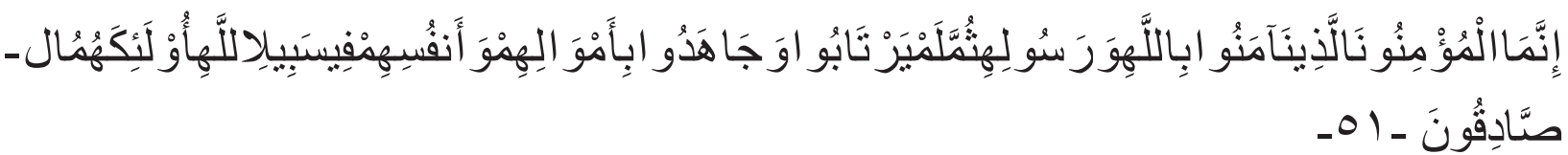

"Sesungguhnya orang-orang yang beriman kepada Allah dan Rasulnya, kemudian mereka tidak ragu-ragu dan mereka berjihad dengan jiwa dan raga mereka pada jalan Allah. Mereka itulah orang-orang yang sabar" (QS. Al-Hujurat : 15)

1 Juhaya S Praja. 2010, Pemikiran Ketatanegaraan Islam, Pustaka Setia, Bandung, hal 13 
Dalam pandangan agama-agama, terutama Islam perang merupakan salah satu ajaran agama yang diatur dalam kitab suci Al-Qur'an. Ayat-ayat perang sebagaimana yang tercantum dalam Al-Qur'ân mengandung makna yang kontroversial. Satu sisi perang diartikan sebagai al-jihâd fî sabîlillah yakni bersungguh-sungguh dalam menegakkan jalan Allah $\mathrm{SWT}^{2}$.Namun di sisi lain, perang diartikan sebagai tugas kelompok atau tugas kenegaraanyang menjadi kewajiban seluruh warga negara ${ }^{3}$.Perang merupakan tindakan politik kenegaraan dalam rangka mempertahankan dan menegakkan eksistensi sebuah negara

Dalam konteks sejarah Islam, tidak dipungkiri adanya peperangan yang pernah dilakukan oleh Rasulullah SAW. Tercatat tidak kurang dari 19 sampai 21 kali terjadi ghazwah (perang besar atau perang yang dipimpin Rasulullah langsung), bahkan ada yang mengatakan 27 kali perang, yang melibatkan pasukan besar dan Rasulullah SAW sendiri yang terlibat di dalamnya, atau mengutus pasukan tersebut. Selain dalam bentuk ghazwah, terdapat pula istilah lain dalam sejarah Islam, yaitu yang disebut dengan sariyyah (perang yang tidak dipimpin Rasulullah) atau perang kecil yang terjadi hampir 35 sampai $42 .{ }^{4}$

Dari catatan diatas, kemudian banyak pihak khususnya pihak barat yang menghubungkan islam dengan perang, dengan mengatakan bahwa islam dikembangkan dengan peperangan. Namun perlu untuk diketahui, bahwa perang yang merupakan kekerasan untuk menyelesaikan perkara atau pertentangan antar negara telah terjadi sejak berabad abad sebelum masehi, sebelum kelahiran islam dan hingga sekarangpun tetap terjadi. Meskipun selalu ada usaha utuk meniadakannya. ${ }^{5}$

Perang dalam Islam merupakan bagian dari jihad yang bernilai jika dilakukan di jalan Allah dan ikhlas karena Allah, untuk meninggikan kalimat Allah dengan merealisasikan tujuan diturunkan syari'at Allah. Tujuan syari'at Allah adalah meneguhkan dan memelihara addin, jiwa, harta, kehormatan, keturunan dan akal. Ketika perang yang merupakan bagian dari jihad diartikan sebagai optimalisasi pengerahan potensi untuk membela islam dalam kondisi bahaya dan memajukan islam dalam kondisi aman atau damai, maka perang bukan sebagai tujuan melainkan sarana untuk merealisasikan tujuan syari'at islam. Maka dari sini diketahui bahwa perang dalam islam memiliki tujuan, adab, syarat, rukun dan seni yang sangat indah. Ini yang membedakan perang dalam islam dan perang diluar islam. Hal ini lebih disebabkan karena jihad merupakan syari'at, maka ia memiliki aturan aturan khusus yang harus diperhatikan sebagaimana dalam syari'at ibadah lainnya seperti sholat, puasa, haji dan sebagainya. ${ }^{6}$

Oleh karena itu pada kesempatan kali ini, penulis ingin menguraikan bagaimana jihad dan qital (perang) dalam kebijakan ketatanegaraan islam, meliputi dari konsep jihad dan qital, hukum qital, periodisasi syari'at tentang qital dan adab etika qital dalam islam.

\section{KONSEP JIHAD DALAM HUKUM ISLAM}

Di dalam kamus al-Munajid dikemukakan bahwa kata jihad berasal dari bahasa Arab yang akar katanya terdiri dari jim, ha, dan dal yang dijadikan isim masdar dari kata jahada, yujahidu, jihadan, bab mufa' alah. Menurut kaidah bahasa Arab, bab mufa' alah digunakan untuk menyatakan perbuatan yang dilakukan oleh dua orang atau lebih, yang satu dan lainnya saling berbalasan, dan mengandung perlawanan.

Secara harfiah kata jihad berarti bazala was 'uhu artinya mengerahkan segenap kemampuan atau upaya maksimal. Menurut terminologi fiqh Islam, jihad adalah uapaya maksimal dalam membela

\footnotetext{
2 Sohail H. Hashmi, 1998 , Jihâd, Encyclopedia of Politics and Religion, editor. Robert Wuthnow. Vol.2, Washington, D.C.: Congressional Quarterly, Inc., , hal. 425-426

3 Azyumardi Azra, Prof. Dr.2002, Pergolakan Politik Islam, Gramedia, jakarta, hal 130

4 Hasan, shohihul, 2012. The art of islamic war, muhammadiyah university press, solo, 2012. Hal 37

$5 \quad$ Ibid hal $x x$

6 Hasan, shohihul, 2012. The art of islamic war, muhammadiyah university press, solo, 2012. Hal XXii
} 
(mempertahankan) agama dengan jiwa dan harta dari serangan-serangan orang-orang kafir ${ }^{7}$. Di dalam Ensiklopedi Islam Indonesia, pengertian jihad dibagi kepada jihad dalam pengertian khusus dan jihad dalam pengertian umum. Jihad dalam pengertian khusus adalah perang melawan musuh, sedangkan jihad dalam pengertian umum adalah usaha maksimal dalam menerapkan ajaran Islam serta pemberantasan kemungkaran dan kezaliman, baik terhadap diri pribadi maupun masyarakat. ${ }^{8}$

\section{JIHAD DAN QITAL}

Sebetulnya perang atau dalam terminologi islam dikenal dengan jihad bukanlah konsep utama yang dikembangkan dalam Islam. Perang disyariatkan oleh Islam dalam rangka mempertahankan diri eksistensi Islam dan kaum muslimin. Pensyariatan ini tidak berbeda dengan kewajiban agama lainnya seperti melakukan qishash atau potong tangan bagi pencuri. Setiap hukum diikuti dengan berbagai tehnis operasionalnya, baik sangsi hukum maupun hukum acaranya.

Jihad bukanlah perang yang menjadikan segala hal menjadi faktor dan tujuan. Tapi, jihad hanya terbatas pada perang di jalan Allah. Jika tujuan perang sudah keluar dari koridor ini, maka bukan lagi disebut jihad, tapi perbuatan yang keji, yang ditolak oleh syariat dan aturan Islam.

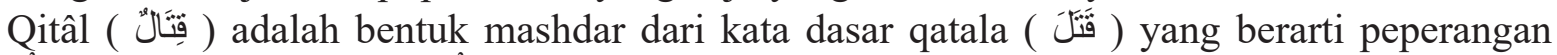

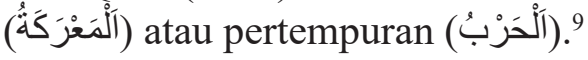

Allah berfirman yang berbunyi :

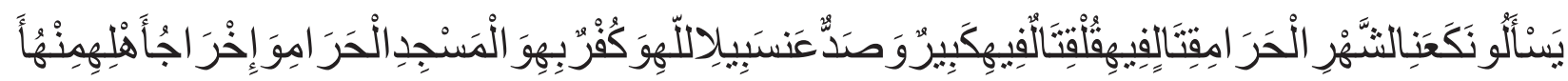

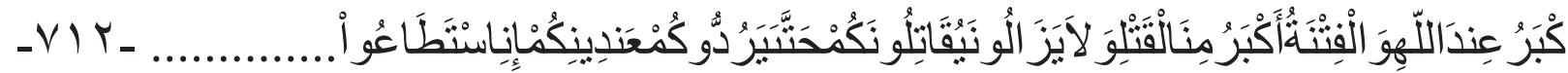

Mereka bertanya kepadamu tentang berperang pada bulan Haram. Katakanlah: "Berperang dalam bulan itu adalah dosa besar; tetapi menghalangi (manusia) dari jalan Allah, kafir kepada Allah, (menghalangi masuk) Masjidilharam dan mengusir penduduknya dari sekitarnya, lebih besar (dosanya) di sisi Allah. Dan berbuat fitnah lebih besar (dosanya) daripada membunuh. Mereka tidak henti-hentinya memerangi kamu sampai mereka (dapat) mengembalikan kamu dari agamamu (kepada kekafiran), seandainya mereka sanggup.... (Q.S. Al-Baqarah[2]: 217)

Kita harus membedakan antara dua istilah yang bisa tercampur dan menimbulkan pemahaman yang negatif dalam mengartikan jihad dalam konteks perang di jalan Allah. Dua istilah tersebut adalah al-qatl (pembunuhan) dan al-qital (peperangan). Perbedaan keduanya sangat jauh. Pembunuhan bermakna upaya membunuh pihak lain dengan senjata. Ini meniscayakan pembunuh di satu pihak, dan terbunuh (korban) di pihak lain. Berbeda dengan peperangan yang meniscayakan dua pihak yang saling menyerang. Masing-masing mengupayakan pembunuhan untuk melawan upaya dari pihak lawan. Makna yang ada dalam istilah "jihad", adalah makna kedua (peperangan), bukan makna pertama, yakni pembunuhan. Kesimpulan akhir dari analisa ini, adalah bahwa perintah jihad dalam Islam, bukanlah perintah membunuh, tapi perintah berperang. Yakni, upaya mempertahankan diri dari serangan musuh, untuk menahan dan menghentikan serangannya

Oleh karena itu Wahbah membedakan antara jihâd dengan harb. Jihad yang dimaksudkan dalam fiqh adalah peperangan atau pertarungan antara umat Islam dengan non-muslim dalam rangka menegakkan nilai-nilai ke Islaman. Sejarah jihad dalam Islam dimulai sejak munculnya berbagai peperangan yang dilakukan pada era Nabi Muhammad ${ }^{10}$. Sementara harb merupakan peperangan antar satu negara dengan negara lain. Konteks peperangan ini bisa juga dilihatdalam

\footnotetext{
7 Wahbah al-Zuhaili, 1963, Atsâr al-Harb fi al Fiqh al islami, Dar al fikr, Damsyiq hal. 413

8 Ensiklopedia Islam, Departemen Agama RI, 1977/1978, hal 451

9 Zaenuri, Lalu A. (2010) . "QITAL DALAM PERSPEKTIFISLAM”. JDIS Vol. 1, No. 1 hal 4

10 Wahbah al-Zuhaili, 1963, Atsâr al-Harb fi al Fiqh al islami, Dar al fikr, Damsyiq hal. 42.
} 
sejarah Islam ketika negara-negara atau kerajaan-kerajaan Islam mempertahankan negara masing$\operatorname{masing}^{11}$

\section{Periodesasi Qital (Perang) dalam al-Qur'an}

Dalam pandangan Syeikh Abd Al-Aziz bin Baz, jihad dalam arti perang dalam Islam terbagi menjadi tiga periode $:^{12}$

a. Periode pertama, umat Islam diizinkan berperang tanpa ada kewajiban untuk itu. Dengan kata lain, perang belum merupakan suatu kewajiban. Hal ini berdasarkan firman Allah dalam surat Al-Hajj:

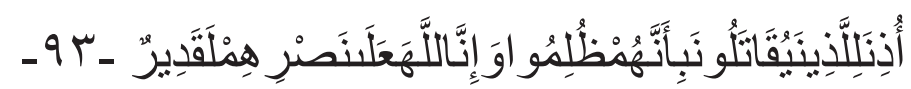

"Telah diizinkan (berperang) bagi orang-orang yang diperanggi karena sesungguhnya mereka telah dianiaya. Dan sesungguhnya Allah benar-benar Maha Kuasa menolong mereka." (Q.S. al-Hajj [22]: 39)

b. Periode kedua, umat Islam diperintahkan untuk memerangi orang-orang yang memerangi mereka saja, sementara orang-orang yang tidak memerangi mereka tidak boleh diperangi. Dalam hal ini Allah berfirman dalam surat al-Baqarah :

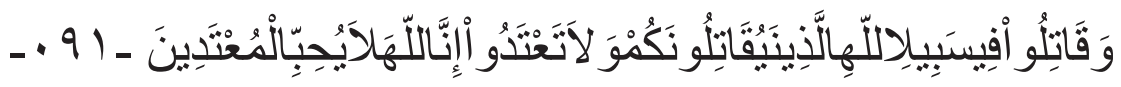

"Dan perangilah di jalan Allah orang-orang yang memerangi kamu, (tetapi) janganlah kamu melampaui batas. Karena sesungguhnya Allah tidak menyukai orang-orang yang melampaui batas." (Q.S. al-Baqarah [2]: 190)

c. Periode ketiga, umat Islam diperintahkan untuk memerangi orang-orang musyrikin secara mutlak, baik mereka yang memerangi umat Islam ataupun tidak. Tujuannya adalah agar kemusyrikan lenyap dari muka bumi dan manusia semuanya tunduk kepada Allah. Hal ini berdasarkan firman Allah dalam surat Al-Anfaal:

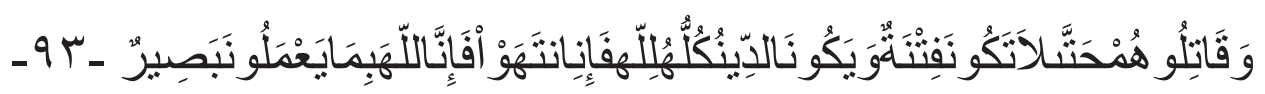

"Dan perangilah mereka, supaya jangan ada fitnah dan supaya agama itu semata-mata untuk Allah. Jika mereka berhenti (dari kekafiran), maka sesungguhnya Allah Maha Melihat apa yang mereka kerjakan. (Q.S. al-Afaal [8]: 39)

\section{Perintah Perang Dalam Al-Qur'an dan Al-Hadist}

Dalam al-Qur'an disebutkan tujuan dan sebab diperbolehkannya melakukan peperangan, di antaranya: ${ }^{13}$

a. Melawan musuh ketika umat Islam dalam suasana perang dan atau diperangi. Dalam hal ini Allah berfirman:

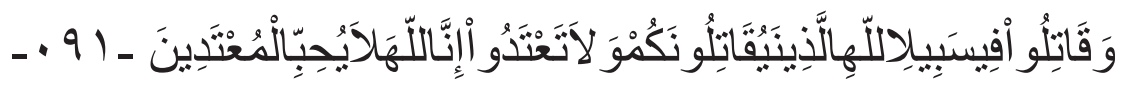

"Dan perangilah di jalan Allah orang-orang yang memerangi kamu, (tetapi) janganlah kamu melampaui batas karena sesungguhnya Allah tidak menyukai orang-orang yang melampaui batas." (Q.S. al-Baqarah [2]: 190)

"Melampaui batas" disini, sebagai contoh membunuh wanita, anak kecil, orang tua, merusak tanaman, membunuh hewan (ternak) tanpa alasan yang jelas (kecuali hewan tersebut dibunuh untuk dimakan).

\footnotetext{
11 Marshall G.S. Hodgson,2002. The Venture Of Islam, Paramadina, Jakarta, hal 273

12 Ibid hal 23

13 Zaenuri, Lalu A. (2010) . “QITAL DALAM PERSPEKTIF ISLAM”. JDIS Vol. 1, No. Ihal 12
} 
b. Menolong orang-orang Muslim yang ditindas oleh orang-orang kafir. Allah berfirman: Mengapa kamu tidak mau berperang di jalan Allah dan (membela) orang-orang yang lemah baik laki-laki, wanita-wanita maupun anak-anak yang semuanya berdoa:

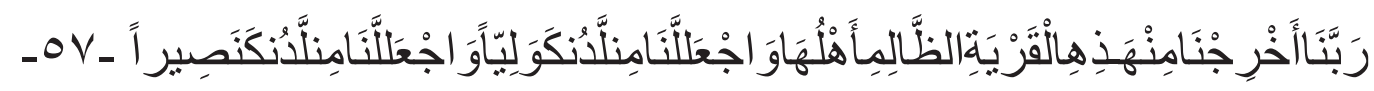

"Ya Tuhan kami, keluarkanlah kami dari negeri ini (Mekah) yang dzalim penduduknya dan berilah kami pelindung dari sisi Engkau, dan berilah kami penolong dari sisi Engkau!" (Q.S. al-Nisa' [4]: 75)

c. Umat Islam sengaja memerangi orang-orang kafir bila mereka menolak ajakan untuk masuk Islam dan/atau mereka merintangi orang-orang Islam agar tidak memiliki kekuasaan karena orang-orang Islam akan memberlakukan hukum (syariah) Islam di muka bumi ini. Perang jenis ketiga inilah yang dinilai oleh sebagian orang sebagai perang yang tidak beralasan atau tidak mempunyai dasar yang jelas. Padahal sebenarnya, baik Al-Qur'an maupun hadis Nabi menunjukkan adanya perang jenis ketiga ini, misalnya Allah berfirman:

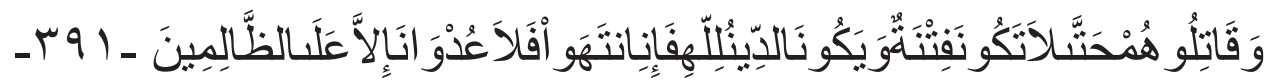

Dan perangilah mereka itu, sehingga tidak ada fitnah lagi dan (sehingga) ketaatan itu hanya semata-mata untuk Allah. Jika mereka berhenti (dari memusuhi kamu), maka tidak ada permusuhan (lagi), kecuali terhadap orang-orang yang dzalim. (Q.S. al-Baqarah [2]: 193)

Fitnah yang dimaksud dalam ayat ini adalah kekafiran dan kemusyrikan. Di samping itu Allah juga berfirman:

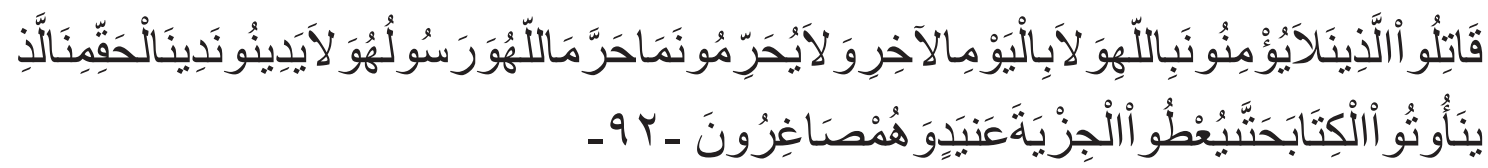

"Perangilah orang-orang yang tidak beriman kepada Allah dan tidak (pula beriman) kepada hari kemudian dan mereka tidak mengharamkan apa yang telah diharamkan oleh Allah dan Rasul-Nya dan tidak beragama dengan agama yang benar (agama Allah), yaitu orang-orang yang diberi Al-Kitab sampai mereka membayar jizyah (pajak) dengan patuh sedang mereka dalam keadaan tunduk.” (Q.S. al-Taubah [9]: 29)

Ayat ini menegaskan bahwa perang yang dilakukan oleh orang-orang Islam adalah bertujuan untuk menegakkan agama Islam dengan memberlakukan syariah Islam setelah orang-orang Islam itu memperoleh kekuasaan, bukan bertujuan untuk membunuh orangorang non muslim. Sebab, seandainya tujuan perang itu untuk membunuh orang-orang non muslim, tentulah tidak ada ketetapan tentang aturan jizyah (pajak keamanan atas mereka) dan tentunya pula orang-orang yang bukan muslim itu tidak dibiarkan tetap memeluk agamanya.

Sebenarnya, perang jenis ketiga ini adalah untuk kepentingan orang-orang musyrikin juga, sebab dengan perang ini di satu sisi umat Islam ingin menghilangkan kekuasaan orangorang kafir dari mereka dan melenyapkan simbol-simbol kebatilan. Sementara itu, di sisi lain, umat Islam juga ingin memperlihatkan ajaran-ajaran Islam kepada mereka, bahkan kepada seluruh manusia. Sehingga bagi mereka yang mengetahui ajaran-ajaran itu kemudian ingin masuk Islam, mereka dengan mudah dapat masuk Islam. Dan bagi mereka yang ingin tetap memeluk agamanya, Islam juga tidak menghalang-halanginya. Islam tetap memberikan kebebasan kepada mereka untuk memeluk agamanya, sementara mereka diwajibkan tunduk kepada peraturan-peraturan umum dalam Negara Islam. 


\section{Gencatan Senjata (Perjanjian Perdamaian)}

Dalam al-Qur'an tidak dibenarkan melakukan penyerangan (secara mendadak), jika sebelumnya ada perjanjian perdamaian (gencatan senjata) dengan suatu kelompok. Penyerangan dapat dilakukan (kepada pihak/kelompok yang melanggar perjanjian), jika pihak yang telah sepakat melakukan perjanjian perdamaian telah melanggar isi dari perjanjian yang telah disepakati (oleh masing-masing pihak) ataupun jika ada pihak yang melanggar isi perjanjian sebelum jatuh tempo habis masa berlakunya kesepakatan perjanjian tersebut. Allah berfirman:

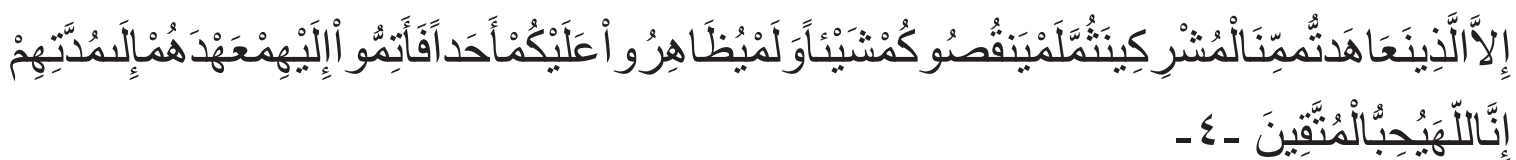

"kecuali orang-orang musyrikin yang kamu telah mengadakan perjanjian (dengan mereka) dan mereka tidak mengurangi sesuatu pun (dari isi perjanjian) mu dan tidak (pula) mereka membantu seseorang yang memusuhi kamu, maka terhadap mereka itu penuhilah janjinya sampai batas waktunya. Sesungguhnya Allah menyukai orang-orang yang bertakwa." (Q.S. al-Taubah [9]: 4) Ini menunjukan bahwa kaum musyrik yang mengadakan perjanjian persahabatan dengan kaum muslimin, maka kaum muslimin tidak boleh memerangi mereka. Hanya kaum yang memusuhi dan yang memutuskan ikatan perjanjian dan menyerang kaum muslimin sajalah yang harus diperangi.

Adapun kaum musyrik perorangan, sekalipun ia termasuk golongan kaum yang memusuhi, ia tetap tidak diganggu jika ia mau meminta keterangan tentang Islam (bertobat dan mendirikan shalat dan menunaikan zakat), dan ia diberi jaminan keamanan untuk pulang kerumah sekalipun ia tidak/belum memeluk Islam, sebagaimana al-Qur'an surat atTaubah[9]:6:

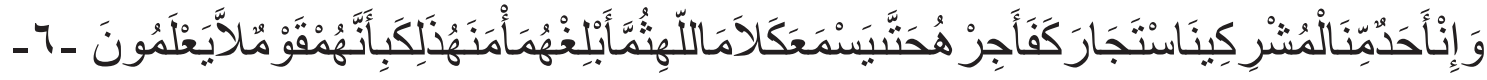

"Dan jika seorang di antara orang-orang musyrikin itu meminta perlindungan kepadamu, maka lindungilah ia supaya ia sempat mendengar firman Allah, kemudian antarkanlah ia ke tempat yang aman baginya. Demikian itu disebabkan mereka kaum yang tidak mengetahui."

Perang dalam pandangan Islam merupakan sesuatu yang harus dihindari karena Islam tidak menghendaki terjadinya peperangan. Perang bisa dilakukan setelah melakukan berbagai cara untuk melakukan negosiasi perdamaian tetapi hal itu tidak ditanggapi oleh pihak musuh, sehingga tidak ada cara lain untuk menyelesaikannya kecuali dengan melakukan perang . Hal itu juga dalam keadaan darurat serta terpaksa ketika pihak lawan yang memulai lebih duluan mengobarkan genderang perang. Dalam melakukan peperangan Islam mempuyai suatu tujuan tersendiri dimana perang dilakukan dengan tujuan untuk mempertahankan diri dari serangan musuh dan dalam rangka menjaga penyebaran da'wah, sedangkan da'wah itu sendiri merupakan rangkaian dari jihad namun tidak termasuk dalam qital. Itulah qital dalam lingkup fisabilillah yang khusus menjurus kepada pertempuran dan merupakan hanya bahagian dari rangkaian jihad. Jadi jangan dimaknai sempit bahwa jihad itu adalah qital (perang) ataupun sebaliknya (qital itu adalah jihad).

\section{Hukum Qital}

a. Fardu Kifayah. Ini berarti berperang melawan musuh yang kafir atau musuh yang ingin mencelakakan Islam ke negeri tempat kediaman mereka. Wajiblah kaum Muslimin untuk pergi mendatangi tempat itu sebanyak yang diperlukan. Syarat fardu kifayah orang yang berperang adalah : beragama Islam,baligh, berakal, merdeka, laki laki, sehat, dan sanggup berperang. Sanggup berperang di sini bukan hanya dilihat dari sisi 
kecakapan berperangnya saja tetapi juga mencakup bekal, belanja, senjata yang cukup serta sempurna anggota tubuh. ${ }^{14}$

b. Fardu 'Ain. Berperang ketika musuh yang kafir atau yang ingin menghancurkan Islam telah memasuki negeri kaum Muslimin. Hukum perang adalah wajib atau fardhu 'ain dalam tiga hal, yaitu:

1) Apabila musuh telah menyerbu negeri umat Islam, dan dengan demikian fitnah menjadi merajalela.

2) Apabilah kepala negara telah memerintahkan ummat Islam untuk berangkat ke medan perang.

3) Apabila pasukan musuh telah berada dihadapan ummat Islam, maka haramlah ummat Islam lari dari medan perang ${ }^{15}$

Nah, jikalau sudah dalam keadaan begini maka syarat-syarat berperang yang disebutkan dalam perang Fardu Kifayah di atas tidak diperlukan lagi karena setiap penduduk baik pria ataupun wanita dan anak-anak YANG SANGGUP memberikan perlawanan wajib mempertahankan diri dan menolak kedatangan musuh tersebut. Demikian juga penduduk dalam jarak dua hari dalam jarak perjalanan ke tempat pertempuran tersebut juga wajib memberikan pertolongan. Bahkan jikalau kekuatan kaum Muslimin belum mencukupi kekuatannya untuk menghadapi musuh, maka penduduk yang lebih jauhpun wajib memberikan pertolongan.

c. Adab dan Etika Perang dalam Islam

Di dalam Al-Qur'an dan hadits shahih ada banyak aturan dalam berperang, antara lain:

1. Harus memegang janji.

2. Jangan membunuh orang yang tidak memerangi (anak-anak, wanita, orang tua penghuni rumah ibadah, dan sebagainya).

3. Jangan berlebih-lebihan.

4. Jangan mencincang.

5. Jangan merobohkan atau membakar bangunan.

6. Jangan menebang pohon dan merusak tanaman.

7. Tidak membunuh yang menyerah.

8. Memperlakukan tawanan dengan baik.

9. Menerima tawaran damai. ${ }^{16}$

Oleh karena itu maka bisa dugambarkan bahwa perang dalam bersifat defensif artinya, Islam melarang memulai perang terhadap suatu umat atau negara. Motivasi perangnya adalah untuk membela Islam atau ummat Islam yang mendapat perlakuan atau kekerasan oleh suatu kaum a tau negara yang memerangi umat Islam. Perang ini dapat dinamakan Jihad Fii sabilillah. Serta motivasi Islam dalam perang adalah untuk melawan kezaliman dan kebathilan untuk menegakkan kebenaran dan keadilan.

\section{Keutamaan Jihad Fi Sabilillah}

Ada banyak dalil yang menerangkan keutamaan jihad di jalan Allah, diantaranya;

a. Jihad di jalan Allah adalah bisnis yang menguntungkan.
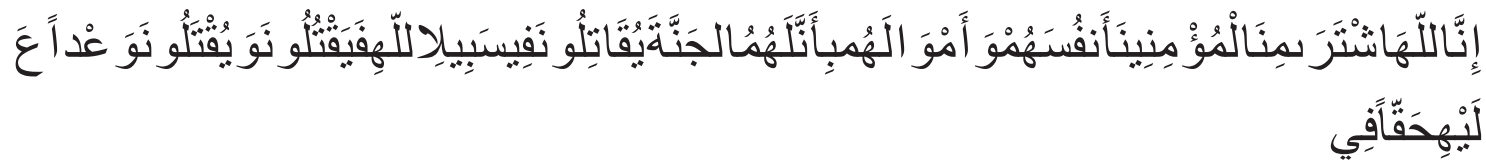

14 Hasan, shohihul, 2012. The art of islamic war, muhammadiyah university press, solo, 2012. Hal 197

15 Ibid hal 198

16 Hasan, shohihul, 2012. The art of islamic war, muhammadiyah university press, solo, 2012. Hal 204 


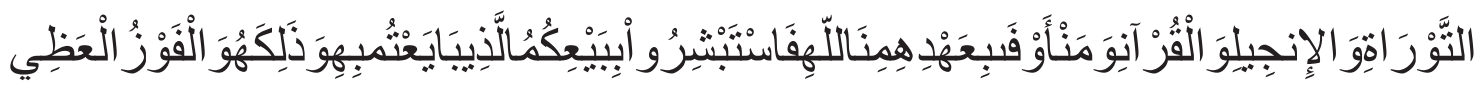

$-111-\stackrel{2}{2}$

"Sesungguhnya Allah telah (berjanji untuk) membeli dari orang-orang mukmin, jiwa dan harta mereka dengan (menganugerahkan) surga untuk mereka. Mereka berperang di jalan Allah. Mereka membunuh dan dibunuh. (Itu telah menjadi) janji atas diri-Nya (sehingga) menjadi janji yang benar, (yang tertulis) di Taurat, Injil, dan Al-Quran. Siapakah yang lebih menepati janji selain Allah?? Maka bergembiralah dengan jual beli yang telah kalian lakukan itu! Itulah kemenangan yang besar." (QS. At-Taubah: 111)

b. Besarnya pahala mereka yang bertahan dan berjaga-jaga di wilayah perbatasan, untuk menghadang serangan musuh. Diriwayatkan dari Salman, Rasulullah saw. bersabda, "Berjaga-jaga di wilayah perbatasan sehari semalam, lebih baik daripada qiyamul lail dan puasa selama sebulan. Jika dia mati (dalam kondisi demikian), pahala amalnya itu dan rezekinya akan dialirkan kepadanya. Dan dia terjaga dari fitnah (huru hara)."

c. Keutamaan berjaga jaga dari serangan musuh dijalan Allah sebagaimana yang Diriwayatkan dari Abu Raihanah: Aku mendengar Rasulullah bersabda, "Api neraka tidak akan menyentuh mata yang meneteskan air mata atau menangis karena takut kepada Allah, dan mata yang terjaga (begadang) di jalan Alllah. Diriwayatkan dari Ibnu Abbas r.a., ia berkata: Aku mendengar Rasulullah bersabda, "Dua mata yang tak akan disentuh api neraka: mata yang menangis karena takut kepada Allah, dan yang terjaga di jalan Allah."

d. Keutaamaan jihad tidak tertandingi, sebagaimana yang telah diriwayatkan dari Abu Hurairah, bahwa seseorang datang kepada Rasulullah saw. dan bertanya, "Tunjukkan kepadaku amalan yang setara dengan jihad!" Rasulullah menjawab, "Tidak ada. Ketika seorang mujahid keluar (untuk berjuang), sanggupkah kamu terus menerus shalat, terus menerus berpuasa? Siapa yang sanggup melakukan itu semua?"17

\section{IKHTITAM}

Kajian sejarah perang dalam sejarah politik Islam merupakan upaya rekonstruksi sejarah perang dalam Islam. Selama ini kajian perang dalam politik Islam lebih dilihat dari kacamata teologis sehingga perang merupakan tugas agama dalam menyebarkan Islam. Tak salah kalau sejarah Islam diplesetkan oleh banyak kaum orientalis sebagai agama pedang, yakni agama yang disebarluaskan dengan pedang

Kata perang sebenarnya sangat tidak disukai islam. Karena kata islam sendiri berarti kedamaian. Rasulullah bahkan pernah bersabda " janganlah kalian berharap bertemu musuh, tetapi mintalah keselamatan kepada Allah dan apabila kalian bertemu musuh maka bersabarlah (teguhkan diri untuk menghadapi mereka" (HR bukhori muslim). Perang dalam islam merupakan pilihan setelah upaya persuasif dengan perdamaian atau perjanjian sudah tidak dimungkinkan lagi

Dari perspektif politik (fiqh siyâsah Dauliyah) perang merupakan bagian dari negara Islam Madinah. Layaknya negara di abad pertengahan bahkan modern sekarang ini, sementara perang pada masa al-khulafâ al-râsyidûn mengalami dinamika baik secara konseptual maupun kelembagaan

Memahami jihad dan perang dalam Islam harus menjadikan sirah nabi muhammad SAW sebagai syarah rukun, syarat, tahapan jihad yang benar. Karena nabi bertugas menjelaskan alqur'an dengan ucapan dan perbuatan, seperti dalam masalah menegakkan negara dan pemerintahan islam dalam situasi sudah adanya negara negara modern dengan segala ideologinya. Apakah dengan mengangkat senjata dan menundukkan penguasa yang ada, merebut pusat pemerintahan kemudian memaksa rakyat untuk berbaiat kepadanya, atau melakukan seperti yang dilakukan

17 Haekal,muhammad khair, Dr. 1996. Al jihad wal qital fi siyasah as syar'iyah. Beirut daru ibnu hajm. Hal 37 
nabi muhammad. Dimana beliau tidak mengumumkan berdirinya negara islam dengan kekuatan senjata, tetapi dengan dakwah sehingga orang orang madinah dengan suka rela menobatkan nabi sebagai kepala negara dan imam mereka. Beliau tidak berperang mengangkat senjata kecuali tlah berdiri negara yang ada wilayahnya dan kaum muslimn sebelum itu kaum muslimin diminta untuk sabar menghadapi gangguan kaum musyrikin.

\section{DAFTAR PUSTAKA}

\section{Al Quran karim}

Ensiklopedia Islam, Departemen Agama RI, 1977/1978

Haekal, Muhammad khair, Dr. 1996. Al jihad wal qital fi siyasah as syar'iyah. Beirut Daru Ibnu Hajm

Hasan, shohihul, 2012. The Art of Islamic War, Muhammadiyah University Press, Solo

Zaenuri, Lalu A. (2010). “Qital dalam perspektif Islam”. JDIS Vol. 1, No. 1

Praja, Juhaya S, Prof, Dr. 2010. Pemikiran ketatanegaraan Islam, Pustaka Setia, Bandung

al-Zuhaili ,Wahbah, 1963, Âtsâr al-Harb fi al Fiqh al islami, Dar al fikr, Damsyiq

Hodgson,Marshall G.S.,2002. The Venture Of Islam, Paramadina, Jakarta 